\title{
SPINAL DEFORMITY AND PARAPLEGIA
}

\author{
By Robert Roa F, M.Ch.Orth., F.R.C.S. \\ Department of Orthopaedics, University of Liverpool
}

\section{INTRODUCTION}

DURING the course of treating a large number of patients with spinal deformities, from time to time one of them has developed a progressive paraplegia; although this is a heterogeneous group from the pathological and aetiological aspects, nevertheless, it is a definite clinical entity and my experience with them may be of sufficient interest in helping other surgeons who are confronted with this problem for it to be worth recording them.

First, I have not included in this group patients with an obvious disorder of the central nervous system who later develop deformity; for instance, children with cerebral palsy, either hemiplegia or diplegia, or children with an established paraplegia due either to trauma, a tumour or a disease such as syringomyelia: such children often develop a spinal deformity with growth. Also, I have not included patients known to have syringomyelia who later develop kyphosis or scoliosis. Equally I have excluded children with primary lower motor neurone and muscular affections; e.g. poliomyelitis, muscle dystrophy, etc. On the other hand, where a child has a spinal deformity and an associated deformity such as a club foot and later develops signs of a spastic paraplegia, I have included these in the series, but I have not included children with meningocoeles and spinal dysraphism, many of whom later develop gross spinal deformities. In some respects the selection has been artificial in that some patients with established kyphosis have developed signs many years later, indicating that they had an intrinsic disease of the central nervous system, but my guiding principle has been that the spinal deformity appeared first, the paraplegia later. This is a definite clinical entity and presents a clear cut problem to the surgeon.

Data. Table I gives a summary of the main facts.

The first and most obvious fact is that there is considerable variation in the course of the condition. In some patients signs of paraplegia develop at a young age and become rapidly progressive and were associated with a congenital abnormality affecting both the vertebral column and the spinal cord, e.g. two of the younger patients with diastematomyelia. In a number of other patients with spinal deformities there has been evidence of a diastematomyelia but without any major neurological disorder; in this connection I have somewhat arbitrarily included as paraplegic any patient with a gross neurological disorder which was sufficiently severe either to interfere with walking, or to impair sphincter control; but I have not included patients with minor neurological signs, e.g. asymmetrical ankle jerks; many patients with spinal deformities have such signs without evidence of impairment of function.

In some patients the presenting sign was failure of sphincter control, and in one patient, there had never been proper bladder control, he had, however, excellent muscular control of his legs until the age of eleven when he suddenly became permanently and completely paraplegic. In two patients, although the onset of symptoms 


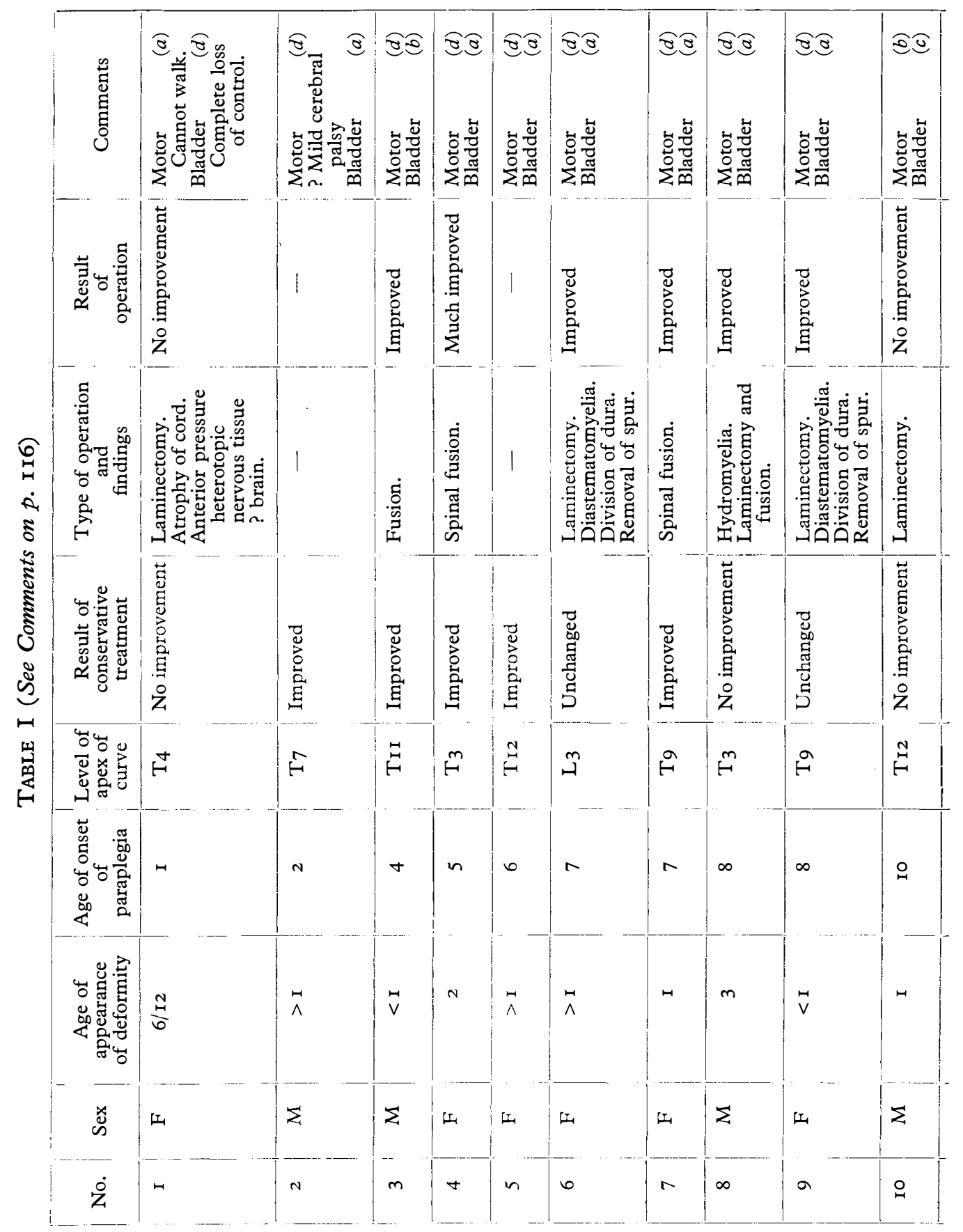




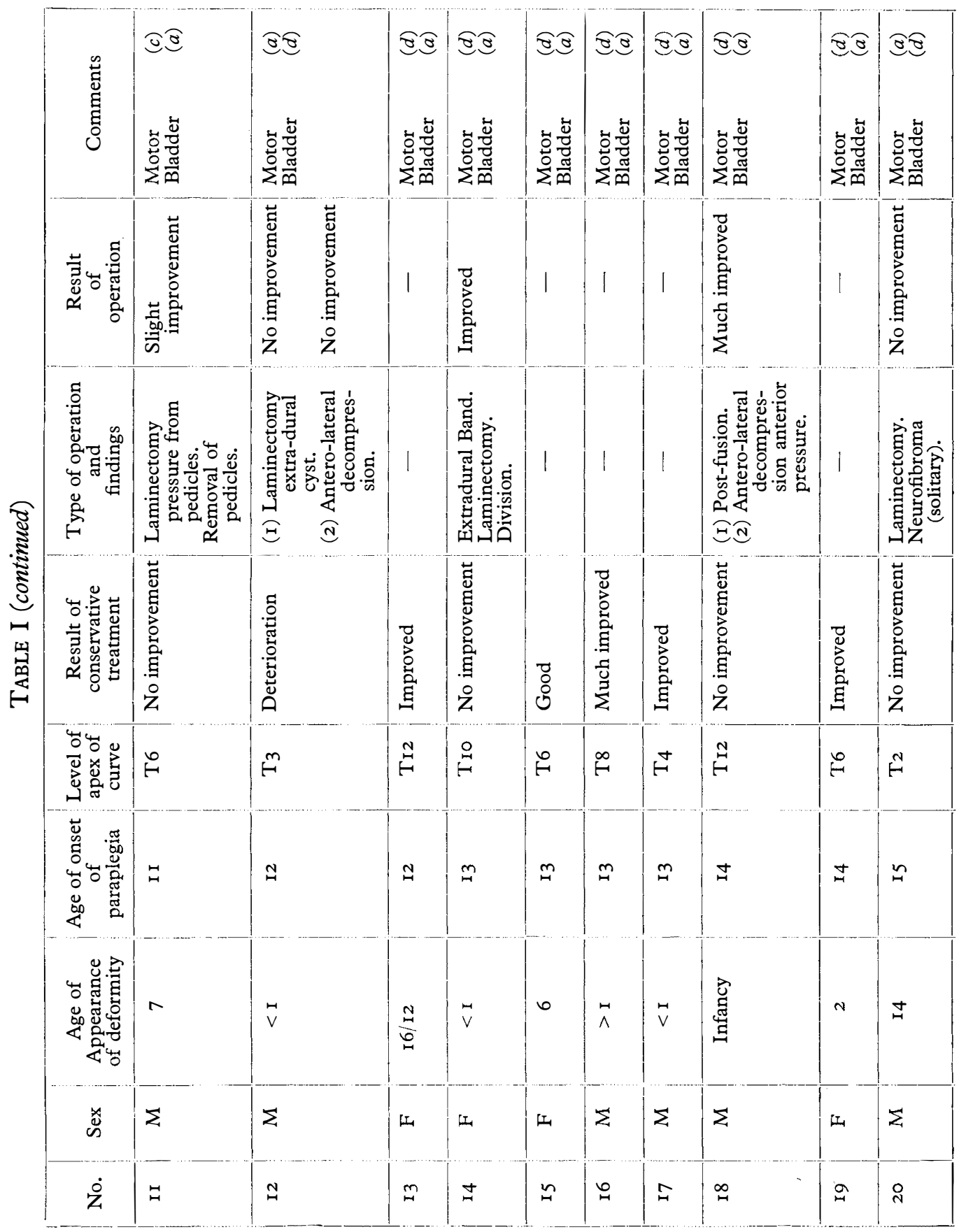




\begin{tabular}{|c|c|c|c|c|c|c|c|c|}
\hline 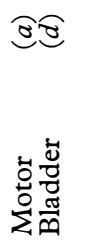 & 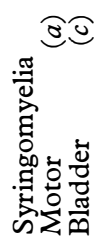 & 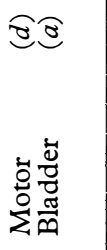 & 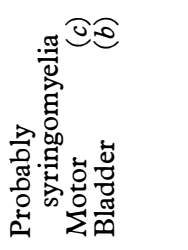 & 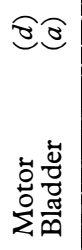 & 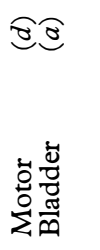 & 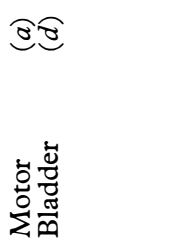 & 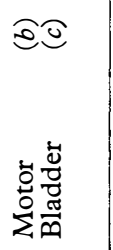 & 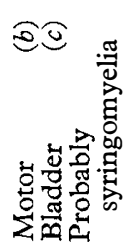 \\
\hline $\begin{array}{l}\infty \\
\infty \\
0 \\
\vdots\end{array}$ & 1 & 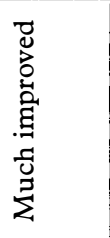 & 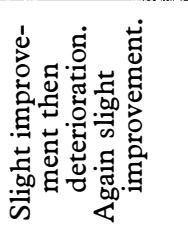 & 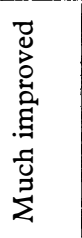 & 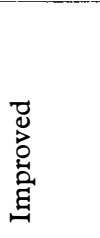 & 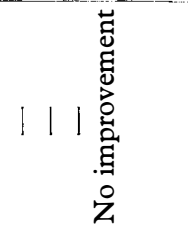 & 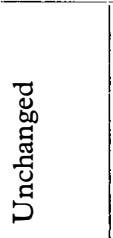 & 1 \\
\hline 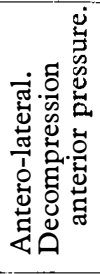 & 1 & 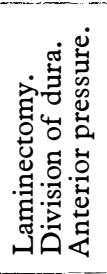 & 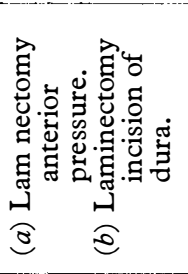 & 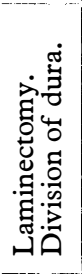 & 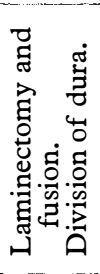 & 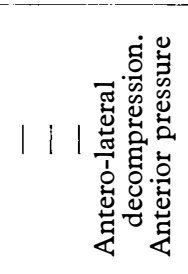 & 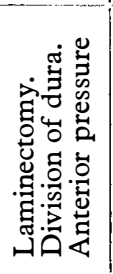 & 1 \\
\hline 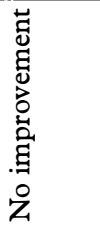 & $\begin{array}{l}0 \\
0 \\
0 \\
0\end{array}$ & 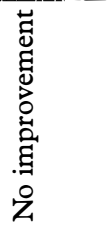 & 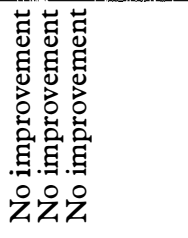 & 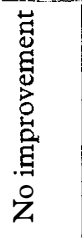 & 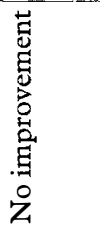 & 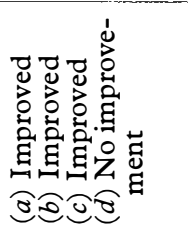 & 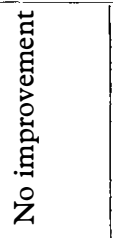 & 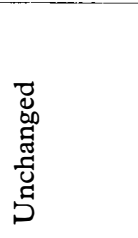 \\
\hline$\stackrel{\circ}{\oplus}$ & $\hat{F}$ & $\stackrel{n}{\oplus}$ & $\hat{\leftarrow}$ & $\stackrel{\sim}{\sim}$ & $\stackrel{N}{\stackrel{N}{H}}$ & $\stackrel{\infty}{\bullet}$ & $\stackrel{9}{\oplus}$ & $\bullet$ \\
\hline$\stackrel{0}{\circ}$ & $\stackrel{\circ}{\circ}$ & $\stackrel{ }{\longrightarrow}$ & $\begin{array}{l}\text { 웡 } \\
\text { 웡 }\end{array}$ & 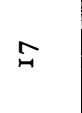 & 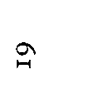 & 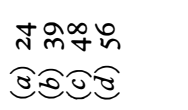 & $\stackrel{\circ}{m}$ & $\stackrel{\infty}{m}$ \\
\hline$H$ & 음 & 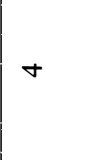 & $\stackrel{\circ}{\longrightarrow}$ & \pm & $\infty$ & $\stackrel{\circ}{\circ}$ & 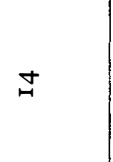 & 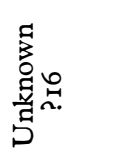 \\
\hline$\Sigma$ & $\Sigma$ & I & $\Sigma$ & $\Sigma$ & $\Sigma$ & $\Sigma$ & $\Sigma$ & $\Sigma$ \\
\hline$\vec{N}$ & $\tilde{N}$ & $\stackrel{\mathcal{N}}{ }$ & $\stackrel{+}{N}$ & $\stackrel{\sim}{N}$ & $\stackrel{\sim}{N}$ & $\hat{N}$ & $\stackrel{\infty}{N}$ & શิ \\
\hline
\end{tabular}




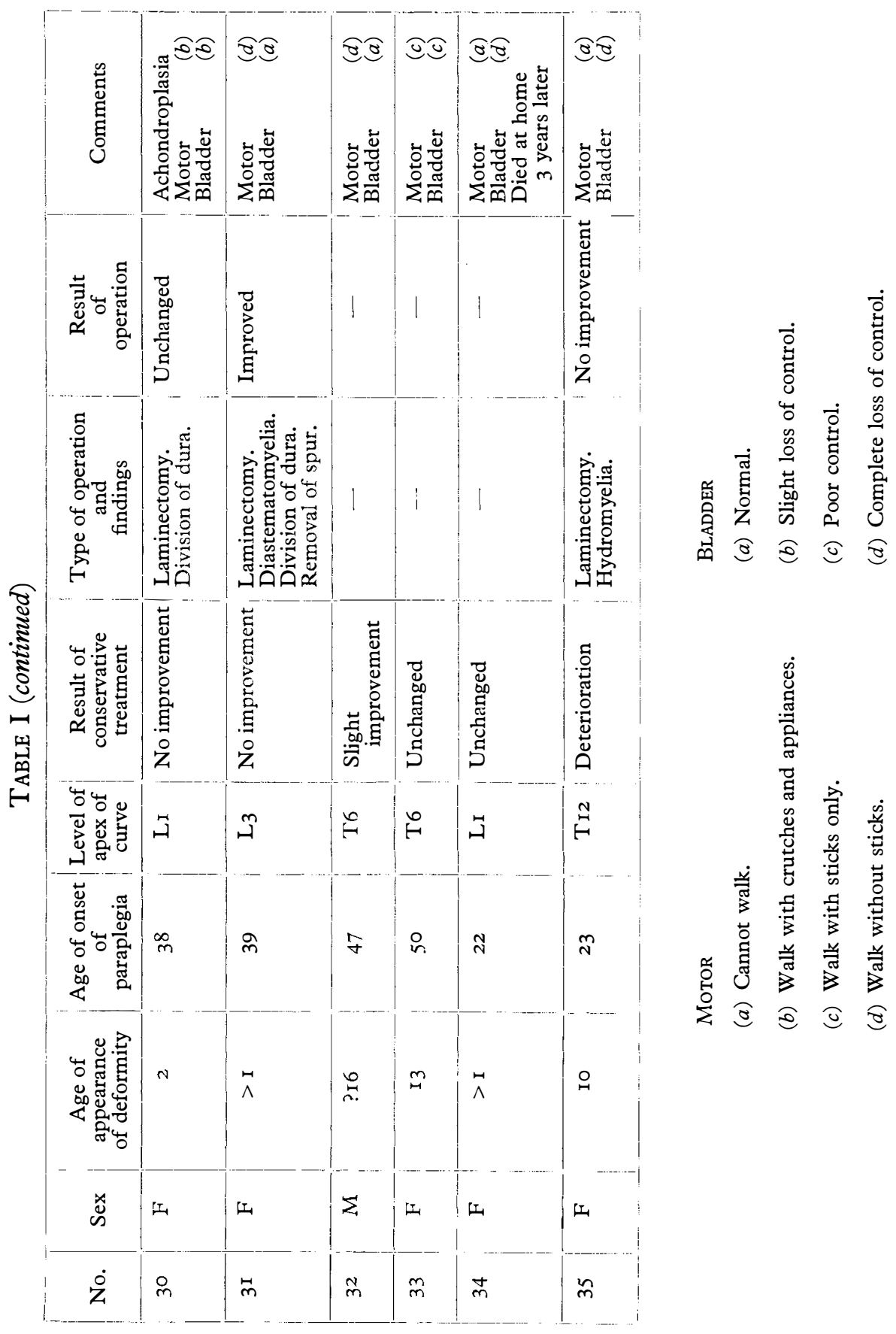


was comparatively early in life, there were long periods of remission, but finally both became grossly paraplegic with evidence of atrophy of the spinal cord. In four patients the onset of the paraplegia was during the course of conservative treatment for the spinal deformity, either in a plaster jacket or in a plaster bed and in two of these the neurological signs improved when the plaster jacket was removed. In ten patients there was an excellent result from simple conservative measuresnamely, recumbency on a plaster bed. In the remaining patients continued deterioration occurred in spite of this conservative treatment. In eight patients the results of a laminectomy, which consisted of removing any compressive agent, e.g. spicule of bone, extra-dural band or pedicles and leaving the dura widely open, resulted in improvement-in some cases, considerable. In seven patients laminectomy did not cause any significant change. In four patients efforts were made to remove the gross bony protrusion at the site of the kyphosis which was protruding into the anterior aspect of the cord. One of these was improved and three were made worse. In these three cases there had been rapid deterioration before operation but it is probable that the operation caused further impairment of an already diminished blood supply to the spinal cord. In three patients there was evidence of hydromyelia but the histological findings were equivocal and did not indicate clearly whether this was an unusual type of syringomyelia or degenerating glioma. In two patients evidence appeared at a later date of widespread disease of the spinal cord suggestive of syringomyelia. The sudden or sub-acute onset of paraplegia in a patient with a spinal deformity suggests that the initial cause of the lesion is ischaemia of the spinal cord and this appears to be the most satisfactory explanation of those patients in whom there was a rapid improvement with conservative treatment or in whom the condition fluctuated.

In each patient the surgeon must ask himself whether the paraplegia is due to the spinal deformity and therefore possibly amenable to orthopaedic treatment, or whether the two conditions are unconnected causally even if associated. For example, both might be due to a common cause but do not influence each other, or lastly, is the spinal deformity secondary to the paraplegia?

To make these points clearer, spinal tuberculosis may be associated with paraplegia and though the paraplegia may be caused in different ways it is usually secondary to the bony disease, treatment of which usually cures the paraplegia. Conversely, the spinal deformity which often develops in a young patient with a paraplegia is probably caused by the muscle imbalance.

\section{DISCUSSION}

In many patients simple recumbency preferably on a plaster bed, and occasionally with skull traction, leads to excellent recovery. In some of these patients a spinal fusion was later performed but it is not yet possible to say whether this improves the late prognosis. In those patients who did not respond to conservative treatment, and in whom the disease was progressive, operative exploration was usually performed. If a removable cause for the paraplegia can be found, e.g. a spur of bone or an extra-dural band, the prognosis is good. In this series it was found that if the pressure was by an anterior ridge of bone, better results were usually obtained from widespread opening of the dura, and leaving it open, than from efforts to remove the projecting spike of bone which may lead to further impairment of the blood supply to the cord. 
In my opinion the most important factor is the preservation of the blood supply to the cord, and in this connection it might be of value to use low molecule dextran solutions such as Rheumacrodex as part of the conservative régime. It is, of course, important that the surgeon should exclude other conditions such as tuberculosis, staphylococcal osteomyelitis, tumours and intrinsic diseases of the central nervous system.

\section{SUMMARY}

The salient features are given of 35 patients with severe non-tuberculous kyphosis who later developed paraplegia.

No correlation could be found between the degree of kyphosis and the neurological impairment. In other words, many patients with similar or more severe deformities do not develop paraplegia.

Symptoms may develop rapidly even though the deformity has not become worse-suggesting that ischaemia is an important factor.

In many patients with kyphosis there is an associated anomaly of the spinal cord, and, understandably, such cords seem to be more vulnerable to pressure.

The aim of treatment is to preserve and improve the blood supply of the spinal cord. In ten patients the response to conservative treatment was good, though a relapse may occur later, in one patient many years later. In some of these patients a spinal stabilising operation was later performed, but it is not possible to compare the remote prognosis in these patients with those treated conservatively-e.g. by spinal braces. In I I patients who did not respond to conservative treatment the results of laminectomy were good if an easily removable compressing agent was found, e.g. an extradural band or, stenosis of the dura, but there was no improvement in patients who already had gross changes in the cord.

In this series the results of removing the anterior bony ridge by anterolateral decompression were mostly poor (though there was one success), contrasting with the excellent results obtained by this method in Pott's paraplegia in the active phase (Roaf, Kirkaldy-Willis \& Cathro, 1959). Paraplegia may be inevitable where there is an associated anomaly of the spinal cord.

In general, paraplegia associated with non-tuberculous kyphosis presents a different problem from Pott's paraplegia.

It is impossible that prevention of the kyphosis in infancy might avoid this distressing complication.

\section{RÉSUMÉ}

Les faits marquants de l'évolution clinique de trente cinq malades avec des kyphoses sévères, non tuberculeuses, qui ont presenté plus tard des paraplègies sont presentés.

Aucun parrallèlisme anatomo-clinique entr ele degré de la kyphose et l'ateinte neurologique n'a pu être trouvé. En d'autres termes, de nombreux malades avec des difformités semblables, ou plus sévères ne furent atteints de paraplègie.

Les symptomes peuvent evoluer rapidement même si la difformité ne s'est pas agravée suggèrant que l'ischemie médulaire est un facteur important.

Chez beaucoup de malades avec kyphose il y a une anomalie associée de la moëlle épinière et de ce fait celle-ci est plus vulnèrable à l'acroissement de la pression.

Le but du traitement est de présèrver et amméliorer la vascularisation de la moëlle épinière. Chez dix malades le traitement conservateur a été éffectif, bien qu'une reprise des symptomes est possible ultèrieurement, chez un des malades plusieures années après.

Chez quelques une de ces malades une opération stabilisatrice du rachis a été éffectuée 
ulterieurement; mais il n'est pas possible ici de comparer le prognostic ulterieur de ces malades avec ceux qui ont reçu un traitement conservateur-i.e. par corsets orthopédiques.

Chez onze malades qui n'ont pas repondu au traitement conservateur les résultats de la laminectomie ont été bons si l'agent de compression médullaire a été trouvé: i.e. une protrusion extradurale ou une sténose de la dure-mère. Aucune ammelioration ne s'est montrée chez les malades avec des altèrations majeures de la moëlle épinière.

Dans la serie qui presentée les resultats de l'ablation de la protrusion osseuse anterieure par décompression antero-latèrale furent pour la plupart pauvres (bien qu'un cas fut une reussite), ceci contrastant avec l'excellent resultat qui est obtenu par cette méthode dans la paraplègie du mal Pott dans la phase active (Roaf et al., I959). La paraplègie peut être inevitable quand il y a une anomalie associée de la moëlle épinière.

En génèral, la paraplègie associée à la kyphose non tuberculeuse presente un problème diffèrent de celle du mal de Pott.

Il est possible que le prévention de la kyphose dés l'enfance puisse faire eviter cette complication déplorable.

\section{ZUSAMMENFASSUNG}

In 35 Fallen mit schwerer nicht-tuberkulöser Kyphose, bei denen sich später eine Paraplegie entwickelte, werden die prominenten Symptome geschildert.

Eine Korrelation swischen Grad der Kyphose und neurologischem Deficit wurde nicht gefunden. Patienten mit gleichen und schwereren Deformitäten haben keine Paraplegie entwickelt.

Neurologische Symptome können rapide enstehen, obwohl keine Zunahme der Deformität eingetreten ist, was dafür spricht, dass Ischämie ein wichtiger Faktor ist.

In vielen Patienten ist die Kyphose mit einer Anomalie des Rückenmarks verbunden, und verständlicherweise ein solches Rückenmark ist mehr vulnerabel.

Das Ziel der Behandlung ist, die Blutcirculation zu erhalten und zu verbessern. Bei Io Patienten war die konservative Therapie erfolgreich. Aber Rückfälle können viele Jahre später erfolgen. In einigen Fällen wurde später eine stabilisierende Operation ausgeführt. Es ist aber nicht möglich, die Spätprognose in diesen Fällen mit den konservativ behandelten Fällen (Stützkorsettbehandlung) zu vergleichen.

In I I Patienten, bei denen die konservative Behandlung versagte, waren die Resultate mit der Laminektomie gut, wenn eine leicht entfernbare Kompression, z.B. ein extradurales Band oder eine Stenose der Dura gefunden wurde. Aber in Fällen, wo bereits schwere Veränderungen des Rückenmarks bestanden, erfolgte keine Besserung.

Entfernung eines vorderen Vorsprungs durch antero-laterale Dekompression ergab schlechte Resultate in Kontrast zu den guten Resultaten, die mit dieser Methode im acuten Stadium bei Pott's Paraplegie erzielt werden kann (Roaf et al., 1959). Paraplegie ist unvermeidlich, wenn eine associierte Anomalie des Rückenmarks besteht.

Im allgemeinen stellt die auf nicht-tuberkulöser Grundlage beruhende Paraplegie ein von der Pott's Paraplegie unterschiedliches Problem dar. Es ist möglich, dass die Verhütung einer Kyphose in der Kindheit diese gefährliche Komplikation verhinden könnte.

\section{REFERENCES}

Roaf, R., Kirkaldy-Willis \& Cathro (1959). Surgical treatment of Bone and foint Tuberculosis. Edinburgh: Livingstone. 